\title{
ON THE EFFICIENCY FACTOR FOR INDUCTION MOTOR AT NON-SINE SUPPLY
}

Purpose. Getting an analytical expression for calculating the efficiency factor for the induction motor with sine supply when connecting it to semiconductor converters of voltage or frequency. The task involves determination of influence of the harmonic components of the stator current on the efficiency factor for motor.

Methodology. The method for determining efficiency factor is based on the laws of energy conservation, Ampere, Kirchhoff and Faraday, the method of harmonic analysis, the principle of superposition for instantaneous power and the methods of the theory of electric machines.

Findings. The equation of the electric power balance is obtained for the harmonic components of the power of an induction motor with its non-sinusoidal power supply. An analytical expression is obtained for determining the efficiency of an induction sine-wave motor when connected to semi-conductor converters of voltage or frequency. An example of calculating the efficiency factor for induction motor of sine supply and the coefficient of its use when connected to a thyristor converter of voltage is given.

Originality. The power balance equation for an induction motor for harmonic components of current is further developed. Unlike the known ones, it takes into account the mechanical component of power. For the first time, the concept of the brake harmonic coefficient was introduced as the ratio of the sum of the effective values of the harmonics of the stator current inverse and zero sequence to the actual value of non-sinusoidal currents, which allows a quantitative estimate of the efficiency reduction. The analytical expression for determination the motor efficiency when supplied by converters of voltage or frequency has been improved.

Practical value. Analytical expression for determining the efficiency of an induction motor of sine supply when connected to semiconductor converters of voltage or frequency allows calculating the factor of using of motor of mechanical power, taking into account the permissible heating by non-sine current.

Keywords: induction motor, non-sine current, efficiency factor, semiconductor converters

Introduction. The electric motor has an important role in the circuit of electricity transmission and its transformation in the technological process. The latter is an electrical energy converter into the mechanical operation of process equipment and provides process requirements. The electric motor, together with the process equipment, is an electromechanical system that has a total efficiency factor (EF). The total efficiency factor consists of the efficiency of individual circuits of the process, including that from the electric motor. The problem of energy saving must be solved by all means, including the means for controlling electromechanical energy conversion.

Asynchronous sinusoidal motors of general purpose for industrial plants are widely used for ventilation and pumping installations. Mine fans supply clean air to workers' workplaces. Pumps pump groundwater to the surface. Fans and pumps resist the speed of rotation of the motor.

Asynchronous motors consume, on the one hand, active power as the rate of inverted conversion of electricity into thermal and mechanical work, and on the other hand, reactive power as the rate of inverted conversion of electric field energy into magnetic field energy and vice versa. Thus, any AC motor has the following energy parameters: efficiency, which determines the efficiency of electromechanical energy conversion and power factor, which determines the efficiency of consumption.

The technological process of regulating the supply of air and water is implemented with mechanical dampers. The latter increase the pressure in the air and water supply systems and increase the consumption of electricity.

To achieve energy efficiency, it is necessary to control the speed of electric motors using semiconductor voltage or frequency converters. The engines consume a non-sinusoidal current with higher harmonics, which, when heated by its windings, do not create torque on the shaft. This means that the rated motor efficiency decreases and therefore the rated mechanical power on the shaft decreases. Thus, when choosing a motor to power from semiconductor converters, it is necessary to check its mechanical power based on the quantitative

(C) Kovalova Yu.V., 2020 evaluation of the efficiency, therefore, the subject of the article is relevant.

Literature review. In [1], the influence of controlled electric drive on the energy efficiency of technological processes is analyzed, and it is shown that in order to increase the overall efficiency of technological equipment, it is necessary to pay attention to the lowest-performing link and to ensure energy efficiency improvement here. As a rule, this link is often an induction motor. In [2], a non-sinusoidal instantaneous power graph for the induction motor supply from a thyristor stator voltage regulator was obtained and a harmonic analysis was performed. [3] shows the reliability of the use of the superposition method for instantaneous non-sinusoidal power, but the effect of harmonic components on the motor efficiency is not evaluated.

In the general case, the efficiency of the motor can be determined in two ways: through the equation of balance of engine power and through the calculation of power losses. In [4, 5], it is proposed to determine the efficiency of an induction motor with thyristor power to determine the rotor sliding, but without taking into account the harmonic current composition, and in [6] - through the calculation of power losses based on its two-phase model, which makes it impossible to estimate the quantitative influence of higher harmonics of current on torque and efficiency.

In $[7,8]$ the peculiarities of the influence of the thyristor frequency converter circuits on the amplitude and time of oscillations of the electromagnetic moment are considered, but the dependence of the harmonic components of the moment on the thyristor control angle is not shown. In [9] the balance of instantaneous capacities of a generalized electric receiver at a non-sinusoidal current is recorded as a function of time through components of a two-phase model without taking into account mechanical power, which does not allow quantifying the efficiency.

Thus, the known literature does not consider the quantitative effect of non-sinusoidal power of the induction motor on its efficiency.

Purpose. The purpose is to obtain an analytical expression for calculating the efficiency of an induction motor of a sinu- 
soidal power supply when it is connected to semiconductor converters of voltage or frequency. The task is to determine the effect of the harmonic composition of the stator current on the motor efficiency. To achieve this goal, it is necessary to obtain the power balance equation of the induction motor for the harmonic components of the non-sinusoidal current.

Results. Instantaneous power at non-sinusoidal current in [9] is recorded as a function of time through the components of a two-phase model of a generalized electric receiver. For an induction motor, a non-sinusoidal current according to the superposition principle [3] is the sum of the harmonic components. To obtain an instantaneous power balance equation for $k^{\text {th }}$ harmonics of voltage and current, we use the classical complex instantaneous power recording form. To do this, we multiply the equilibrium equation of the stator phase winding in complex form by the coupled current complex and we obtain

$$
\dot{U}_{s k} \stackrel{*}{I}_{s k}=R_{s} I_{s k}^{2}+j X_{s k \sigma} I_{s k}^{2}+j X_{s k o} I_{s k}^{2},
$$

where $\dot{U}_{s k}$ is the complex of the acting value of the $k^{\text {th }}$ harmonic of the stator voltage; $I_{s k}$ is the complex of the acting value of the $k^{\text {th }}$ harmonic of the stator current is coupled; $I_{s k}$ is the current value of the current as a real number after multiplying the current complex by its conjugate complex; $X_{s k o}, X_{s k}$ are stator winding inductors for $k^{\text {th }}$ harmonic current: basic and scattering; $R_{s}$ is active resistance of the stator phase winding.

The left side of equation (1) is the total power of the $k^{\text {th }}$ harmonic of the stator winding consumed from the electrical network; the first term of the right part is the active power, which is converted into the thermal work of heating the stator winding; the second and third terms are the reactive power that is converted into a magnetic field in the stator and rotor cores and in the air gap between them.

A rotor winding is a set of electrical circuits connected in parallel to a short-circuited rotor or connected to a threephase "star" circuit for three phase windings of the rotor. Each of the electrical circuits has an area equal to the longitudinal section of the magnetic core of the rotor along the axis of rotation $S_{p}=D_{p} \cdot L_{p}$, where $D_{p}, L_{p}$ are diameter and length of the magnetic core. According to the law of electromagnetic induction of Faraday, in each electric rotor circuit whose area intersects the moving vector $B_{s k}$ of the magnetic induction of the stator with an angular velocity $\omega_{s k}$, the electromotive force harmonic (EMF) is induced. The latter is proportional to the area of the circuit and the frequency of its intersection with the magnetic field $\left(\omega_{s k}-\omega_{r}\right)$, where $\omega_{r}$ is the angular mechanical speed of the rotor. At times when the contour area is perpendicular to the moving vector $B_{s k}$ of the magnetic induction of the stator, the complex of the active value of the EMF of the rotor is

$$
\dot{E}_{r k}=C_{p} B_{s k} S_{p}\left(\omega_{s k}-\omega_{r}\right),
$$

where $C_{p}$ is the design coefficient of the rotor, the value of which is proportional to the number of grooves of the rotor and the number of conductors in the grooves (for short-circuited it is one). It should be noted that a similar design factor is also used for DC motors.

With a closed rotor winding there is a current and an equilibrium equation for the $k^{\text {th }}$ harmonics of the EMF and the rotor current with (2) and the corresponding algebraic transformations has the form

$$
C_{p} S_{p} B_{s k} \omega_{s k}=R_{r} \dot{I}_{r k}+j X_{r k \sigma} \dot{I}_{r k}+C_{p} S_{p} B_{s k} \omega_{r},
$$

where $R_{r}, X_{r k \sigma}$ are active and inductive impedance of rotor winding for $k^{\text {th }}$ harmonic current. Note that the expression $C_{p} S_{p} B_{s k} \omega_{s k}=E_{r k 0}$ is the EMF of the rotor at its zero speed. After multiplying (3) by the conjugate complex of the current value, we obtain the power balance equation for the $k^{\text {th }}$ harmonic of the rotor power

$$
\dot{E}_{r k 0} \stackrel{*}{I}_{r k}=R_{r} I_{r k}^{2}+j X_{r k \sigma} I_{r k}^{2}+C_{p} S_{p} B_{s k} I_{r k} \omega_{r} .
$$

The left part (4) is the total power of the $k^{\text {th }}$ harmonics of the voltage and current of the rotor phase, the first term of the right part is the active power of the $k^{\text {th }}$ harmonic, the current that is converted into the thermal work of heating the winding; the second term is the reactive scattering power of the $k^{\text {th }}$ harmonic of the rotor current generated by the magnetic scattering flows that are closed through the air gap between the stator and rotor cores. We show that the third term of equation (4) is the mechanical power on the motor shaft $P_{k p}=M_{k} \omega_{r}$ for the $k^{\text {th }}$ harmonic of the voltage and current of the rotor. To do this, we express the area of the longitudinal cross section $S_{p}$ of electrical circuits through its radius $R_{p}$ and length $L_{p}$, that is, $S_{p}=$ $=2 R_{p} \cdot L_{p}$. Then $C_{p} S_{p} B_{s k} I_{r k}=2 C_{p} R_{p} B_{s k} L_{p} I_{r k}=2 C_{p} R_{p} F_{k}=M_{k}$ is the torque of the rotor according to the law of Ampere, according to which the force acting on one conductor of the electrical circuit is equal to $F_{k}=B_{s k} L_{p} I_{r k}$.

We express the harmonics of the EMF and the rotor current through the stator parameters using the coefficient of transformation $K_{T}$ between the windings

$$
\dot{E}_{r k 0}=\dot{U}_{s k} / K_{T} ; \quad \dot{I}_{r k}=\dot{I}_{s k} \cdot K_{T} .
$$

Then the power balance equation for the $k^{\text {th }}$ harmonic of the rotor power (4) with (1) takes the form

$$
R_{s} I_{s k}^{2}+j X_{s o k} I_{r k}^{2}+j X_{s \sigma k} I_{s k}^{2}=R_{r} I_{r k}^{2}+j X_{r \sigma k} I_{r k}^{2}+M_{k} \omega_{r} .
$$

Equation (6) matches the law of conservation of electricity for $k^{\text {th }}$ harmonics, i.e., the left side is the full power of the stator consumed from the electrical network. The right part is the full rotor power, which is equal to thermal power, reactive scattering power and mechanical power. The active power component includes all the power losses in the engine.

According to the method of symmetric components [9], the harmonics of voltage and current No. 1,7,13 have a direct sequence and create electric motor torque in the forward direction; harmonics No. 5,11 of the reverse sequence create the opposite (brake) moment; harmonics No. 3,9 of zero sequence have no phase shift and create a fixed magnetic field and therefore a brake moment.

Thus, in the case of non-sinusoidal power supply to the induction motor designed for sinusoidal power supply, only harmonics of the current of the stator and rotor of direct sequence create torque on the shaft, and the squares of the acting values of all harmonics generate heating. This means that at rated power consumption at the allowable insulation temperature, a reduction of the motor's rated mechanical load is required. Thus, the rated engine efficiency decreases. To quantify such a decrease, it is necessary to select a generic parameter that does not depend on the engine power. This parameter takes the coefficient of brake harmonics $K_{g g}$, as the ratio of the sum of the valid values of the harmonics of the stator current of the inverted and zero sequence to the current value of the non-sinusoidal current, i.e.

$$
K g g=\frac{I_{s 3}+I_{s 5}+I_{s 6}+I_{s 9}+I_{s 11}}{I_{n s}} .
$$

Since the heating of the motor windings is proportional to the square of the current values of the harmonics of the current, the efficiency at non-sinusoidal power $\eta_{n s}$ relative to the nominal value $\eta_{\text {nom }}$ can be represented as

$$
\eta_{n s}=\left(1-K_{g g}^{2}\right) \eta_{\text {nom }} .
$$

The physical meaning of expression (8) is that as $K_{g g}$ decreases, the efficiency increases. If in the process of speed 
regulation $K_{g g}$ changes in a certain range, then (8) should substitute its mean value.

The motor technical data sheet indicates the rated mechanical power $P_{n}$ on the shaft at which the rated electric power $P_{e l}=P_{n} / \eta_{n}$ heats the winding to a temperature acceptable for insulation. Since $\eta_{\text {nom }}$ decreases with non-sinusoidal power, it is necessary to reduce the load on the motor so that the electrical power does not exceed the nominal value, which matches with the rated mechanical power. In determining it, the mechanical power on the shaft is directly proportional to the efficiency, i.e.

$$
K_{u}=\frac{P_{n s}}{P_{s}}=\frac{\left(1-K_{g g}^{2}\right) \eta_{s}}{\eta_{s}}=1-K_{g g}^{2} .
$$

Thus, when a designer of the working mechanism chooses induction motor of sinusoidal power of the nearest higher power, which must be connected to the semiconductor converter, from the standardized series of catalogs, it is necessary to calculate the reduction of mechanical power and check that the latter is not lower than the power of the working mechanism. If the rated power is less, then a larger motor must be chosen. The last one consumes more electrical power, but on the shaft the mechanical power decreases.

It should be noted that present-day catalogs offer special induction motors for connection to a semiconductor frequency converter, which have an increased diameter of the winding wires and an increased cooling surface. However, it is more expensive than general-purpose engines by about $30 \%$ and in this case, it is necessary to carry out a feasibility study.

As an example of practical use of the presented material, we consider the case of connecting an asynchronous sinusoidal power supply to a thyristor voltage converter with a system of pulse-phase control. The complex nature of the dependence of the current value of the harmonics of the current on the control angle of the thyristors eliminates the possibility of obtaining it in the analytical form. Therefore, it is advisable to determine this dependence experimentally with further ap- proximation by an analytic polynomial. The experiment can be either physical on a laboratory bench or computer-based on a mathematical model. Since induction motors belong to the class of deterministic systems in which the functional dependencies of the parameters are uniquely determined by causation and accurately described by differential equations, it is advisable to carry out a computer experiment.

A computer experiment can be run in different software environments. The MatLab - Simulink software package is the most convenient for modeling.

The model diagram in the MatLab - Simulink software package is shown in Fig. 1. The model contains a voltage source, thyristor voltage converter on thyristors VS1, VS2, pulse-phase control system on "Pulse Generator" blocks for the formation of control pulses for thyristors, T-shaped alternating circuit of the engine, "Garmonika" blocks to determine the amplitude of the brake current and "signal rms" blocks for calculating their operating values, ammeter, voltmeter, display and oscilloscope.

The parameters of the T-shaped alternate circuit are calculated for the engine type 4A112M4U3 with power $P_{2 n}=5.5 \mathrm{~kW}$, $\eta_{n}=85.5 \%$

It should be noted that the induction motor model can also be used with its two-phase model from the Simulink software package library, but the model with the alternate circuit takes less time to simulate, since the mode parameters immediately go to steady state without a transient. Fig. 2 shows the calculated waveforms of the stator voltage and current obtained from model $(a)$ and experimental ones $(b)$ obtained on the laboratory bench in order to verify that the model works correctly, that is, to illustrate its accuracy.

As a result of simulation, the current values of current harmonics were obtained and the coefficient of brake harmonics, coefficients of efficiency and utilization of engine power depending on the control angle of the thyristors are calculated, which are summarized in Table 1.

Fig. 3 shows the plots of relation $\eta_{n s}$ to thyristor control angle obtained from the model (solid line) and approximated

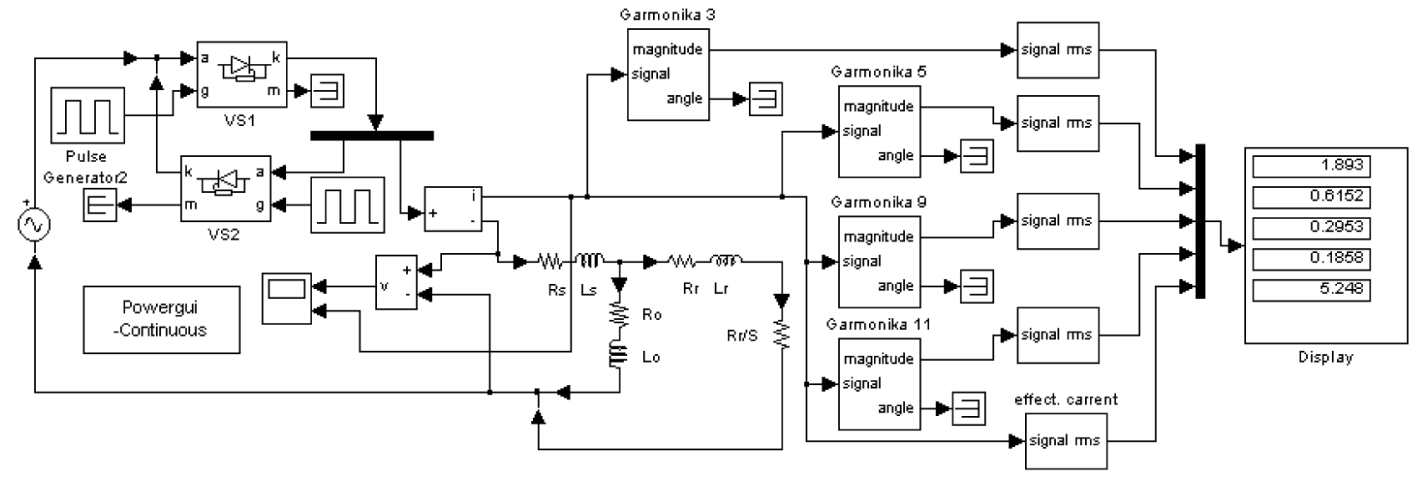

Fig. 1. Simulink model of induction electric drive with thyristor voltage regulator

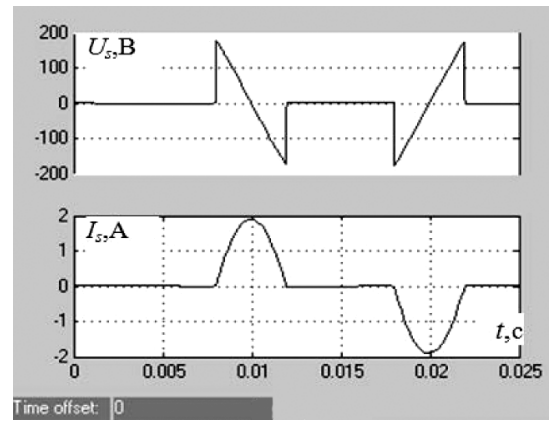

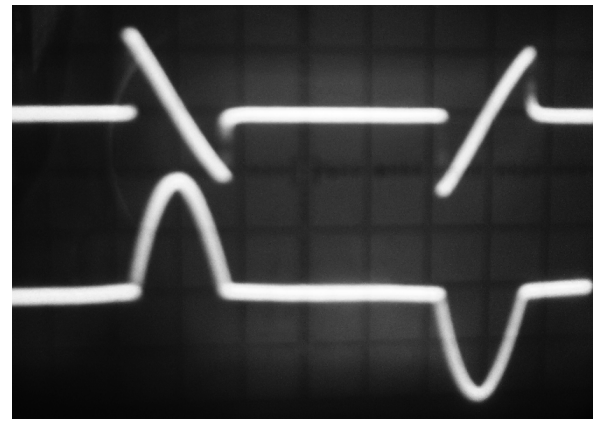

$b$

Fig. 2. Waveforms $U_{s}$ and stator current $I_{s}$ obtained on model (a) and experimental waveforms (b) obtained on a laboratory bench 
The results of the calculation on the model of efficiency

\begin{tabular}{|c|c|c|c|c|}
\hline Name of parameters & \multicolumn{4}{|c|}{ Numeric parameter values } \\
\hline Thyristor control angle, sec/degrees & $0.005 / 90$ & $0.006 / 108$ & $0.007 / 126$ & $0.008 / 144$ \\
\hline Current of $3^{\text {rd }}$ harmonic, A & 1.736 & 1.893 & 1.5 & 0.741 \\
\hline Effective current of $5^{\text {th }}$ harmonic, A & 0.861 & 0.615 & 0.498 & 0.471 \\
\hline Effective current of $9^{\text {th }}$ harmonic, A & 0.319 & 0.295 & 0.206 & 0.09 \\
\hline Effective current of $11^{\text {th }}$ harmonic, A & 0.246 & 0.187 & 0.137 & 0.102 \\
\hline Effective current of stator, A & 7.439 & 5.248 & 3.14 & 1.67 \\
\hline The coefficient of the brake harmonics & 0.266 & 0.385 & 0.51 & 0.532 \\
\hline Coefficient of efficiency & 0.79 & 0.724 & 0.629 & 0.609 \\
\hline Motor utilization rate & 0.929 & 0.852 & 0.74 & 0.717 \\
\hline
\end{tabular}

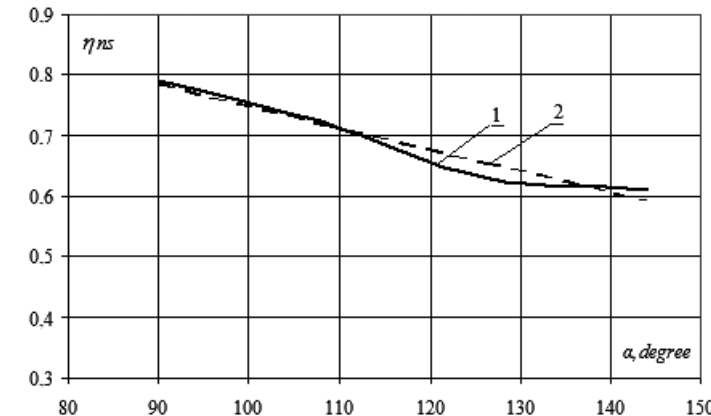

Fig. 3. Graph of the dependence of the efficiency $\eta_{n s}$ of the induction motor on the angle $\alpha$ of the thyristor control obtained on the model (1) and approximated (2)

by the least squares method [10] with the formula $\eta_{n s}=1.33$ $0.00525 \cdot \alpha$ (dashed line).

Conclusions.

1. Theoretical analysis of the process of electromechanical energy conversion with an asynchronous motor is conducted, which resulted in the further development of the equation of the balance of powers of the asynchronous motor for the harmonic components of non-sinusoidal current, taking into account the mechanical power.

2. To quantify the effect of non-sinusoidal current on the engine mode, the concept of brake harmonic coefficient is introduced as the ratio of the valid values sum of the stator current harmonics of the inverted and zero sequence to the active value of the non-sinusoidal current, which allows calculating the magnitude of the efficiency reduction.

3. Analytical expression for determining the efficiency of an induction motor when powered by voltage or frequency converters is improved, taking into account the harmonic components of the zero and inverse currents.

4. The formula for calculating the power factor of a sinusoidal power supply by mechanical power when connected to a semiconductor voltage or frequency converter is proposed.

\section{References.}

1. Beshta, O.S. (2012). Electric drive adjustment for improvement of energy efficiency of technological processes. Naukovyi Visnyk Natsionalnoho Hirnychoho Universytetu, (4), 98-108.

2. Kalinov, A. P., Leiko, V. V., \& Rod'kin, D. I. (2006). Spektrum analysis of instantaneous power in a network polyhapmonics voltage and current. Transaction Kremenchuk State Polytechnical University, (38), 59-64.

3. Rod'kin, D. I. (2003). Principle of superposition in the processes of transformation of energy. Transaction Kremenchuk State Polytechnical University, (28), 80-85.
4. Shurub, Yu. V. (2014). Statistical optimization of induction motors with regulation of voltage. Tekhnichna Elektrodynamika, (5), 116-118.

5. Shurub, Yu. V. (2017). Statistical optimization of induction electrical drives with regulation of freqency. Electrical engineering \& electromechanics, (1), 26-30. https://doi.org/10.20998/2074272X.2017.1.05.

6. Petrushin, V. S., Yakimets, A. M., Plotkin, Yu. R., \& Yenoktayev, R. N. (2018). Investigation of the soft start of an induction motor. Tekhnichna Elektrodynamika, (1), 56-51. https:// doi.org/10.15407/techned2018.01.056.

7. Lobov, V. I., \& Lobova, K. V. (2017). The thyristor converter influence on the pulsations of the electromagnetic torque of the induction motor at parametrical control. Electrical engineering \& electromechanics, (4), 34-41. https://doi. org/10.20998/2074-272X.2017.4.06.

8. Lobov, V. I., Lobova, K. V., \& Fortuna, Ye. O. (2017). Comparison of the mechanical characteristics of an induction motor with various parametric control circuits. Naukovyi Visnyk Natsionalnoho Hirnychoho Universytetu, (1), 88-92.

9. Kim, H.S., \& Akagi, H. (1999). The Instantaneous Power Theory on the Rotating p-q-r Reference Frames. In Proc. IEEE PEDS-12. 422-427. Hong Kong, China. https://doi. org/10.1109/PEDS.1999.794600.

10. Vlasov, K. P. (2002). The method of investigation and organization experimtnts. Kharkov: Gumanitarnyi tsentr.

\section{Про коефіцієнт корисної дії асинхронного двигуна при несинусоїдальному живленні}

\section{Ю. В. Ковальова}

Харківський національний університет міського господарства імені О. М. Бекетова, м. Харків, Україна, е-mail: kovalova.jv@gmail.com

Мета. Отримати аналітичний вираз для розрахунку коефіцієнта корисної дії (ККД) асинхронного двигуна синусоїдального живлення при його підключенні до напівпровідникових перетворювачів напруги або частоти. Задача полягає у визначенні впливу гармонічних складових струму статора на ККД двигуна.

Методика. Методика визначення ККД грунтується на законах збереження енергії, Ампера, Кірхгофа та Фарадея, методі гармонічного аналізу, на принципі суперпозиції для миттєвих потужностей і на методах теорії електричних машин.

Результати. Отримане рівняння електроенергетичного балансу для гармонічних складових потужності асинхронного двигуна при його несинусоїдальному живленні. Отриманий аналітичний вираз для визначення ККД асинхронного двигуна синусоїдального живлення при 
його підключенні до напівпровідникових перетворювачів напруги або частоти. Наведений приклад розрахунку ККД асинхронного двигуна синусоїдального живлення та коефіцієнта його використання при підключенні до тиристорного перетворювача напруги.

Наукова новизна. Отримало подальший розвиток рівняння балансу потужностей асинхронного двигуна для гармонічних складових струму, яке, на відміну від відомих, ураховує механічну складову потужності. Уперше введене поняття коефіцієнта гальмівних гармонік як відношення суми діючих значень гармонік струму статора оберненої та нульової послідовності до діючого значення несинусоїдального струму, що дозволяє провести кількісну оцінку зменшення ККД. Удосконалений аналітичний вираз для визначення ККД двигуна при живленні від перетворювачів напруги або частоти з використанням коефіцієнта гальмівних гармонік струму.

Практична значимість. Аналітичний вираз для визначення ККД асинхронного двигуна синусоїдального живлення при його підключенні до напівпровідникових перетворювачів напруги або частоти дозволяє розрахувати коефіцієнт використання двигуна за механічною потужністю з урахуванням допустимого нагрівання несинусоїдальним струмом.

Ключові слова: асинхронний двигун, несинусоїдальний струм, коефіцієнт корисної дї, напівпровідниковий перетворювач

\section{О коэффициенте полезного действия асинхронного двигателя при несинусоидальном питании}

\section{Ю. В. Ковалева}

Харьковский национальный университет городского хозяйства имени А. Н. Бекетова, г. Харьков, Украина, e-mail: kovalova.jv@gmail.com

Цель. Получить аналитическое выражение для расчета коэффициента полезного действия (КПД) асинхронного двигателя синусоидального питания при его подключении к полупроводниковым преобразователям напряжения или частоты. Задача состоит в определении влияния гармонических составляющих тока статора на КПД двигателя.

Методика. Методика определения КПД основывается на законах сохранения энергии, Ампера, Кирхгофа и Фарадея, методе гармонического анализа, на принципе суперпозиции для мгновенных мощностей и на методах теории электрических машин.

Результаты. Получено уравнение электроэнергетического баланса для гармонических составляющих мощности асинхронного двигателя при его несинусоидальном питании от тиристорных преобразователей напряжения и частоты. Получено аналитическое выражение для определения КПД асинхронного двигателя предназначенного для синусоидального питания при подключении к полупроводниковым преобразователям напряжения или частоты. Приведен пример расчета КПД асинхронного двигателя синусоидального питания и коэффициента его использования при его подключении к тиристорному преобразователю напряжения.

Научная новизна. Получило дальнейшее развитие уравнение баланса мощностей асинхронного двигателя для гармонических составляющих тока, которое, в отличие от известных, учитывает механическую составляющую мощности. Впервые введено понятие коэффициента тормозных гармоник как отношение суммы действующих значений гармоник тока статора обратной и нулевой последовательности к действующему значению несинусоидального тока, что позволяет провести количественную оценку уменьшения КПД. Усовершенствовано аналитическое выражение для определения КПД двигателя при питании от преобразователей напряжения или частоты с использованием коэффициента тормозных гармоник тока.

Практическая значимость. Аналитическое выражение для определения КПД асинхронного двигателя синусоидального питания при подключении к полупроводниковым преобразователям напряжения или частоты позволяет рассчитать коэффициент использования двигателя по механической мощности с учетом допустимого нагрева несинусоидальным током.

Ключевые слова: асинхронный двигатель, несинусоидальный ток, коэффициент полезного действия, полупроводниковый преобразователь

Recommended for publication by V.H. Yahup, Doctor of Technical Sciences. The manuscript was submitted 13.03.19. 